\title{
Effectiveness evaluation of Bacterial Species Isolated from soil in Bioremediation of Diazinon, Pirimicarb and Atrazine Pesticides
}

\author{
Mosaab Abdalmahmoud Hassan*, Aarif El-Mubarak and Yousif Osman Assad \\ Department of Pesticides and Toxicology, Faculty of Agricultural Sciences, \\ University of Gezira, Sudan \\ *Corresponding author
}

\begin{tabular}{l} 
K e y w o r d s \\
Bioremediation, \\
Diazinon, E.coli, \\
Efficiency, S. \\
aureus, S. bongori \\
\hline Article Info \\
\hline $\begin{array}{l}\text { Accepted: } \\
\text { 05 February } 2020 \\
\text { Available Online: } \\
\text { 10 March } 2020\end{array}$ \\
\hline
\end{tabular}

\section{A B S T R A C T}

In the present investigation, bacterial species such as E. coli, S. aureus and S. bongori were isolated from soil by using serial dilution. Bioremediation results showed the $S$. aureus was highly efficient on Diazinon removal by $62 \%, 63.2 \%$ and $68.6 \%$, Pirimicarb removal was $44 \%, 52.4 \%$ and $53.8 \%$, and Atrazine removal was $61 \%, 65.6 \%$ and $70.6 \%$. and the efficiency of $E$. coli removal on Diazinon was $59 \%, 60.8 \%$ and $63.8 \%$; on Pirimicarb was 44\%, 52.4\% and 53.8\%; and for Atrazine 57\%, 60.8\% and 64.4\%. S. bongori efficiency on Diazinon was 49\%, 51.2\% and 55.8\%; on Pirimicarb removal was $61 \%, 63.2 \%$ and $68.4 \%$; Also, in Atrazine removal $48 \%, 50.4 \%$ and $57.2 \%$. When comparing the growth rate of bacterial cells. The bacterial cells before treatment with $S$. aureus was $22.01 \times$, Results after treatment showed Diazinon of $35.58 \times$. The Pirimicarb $32.41 \times$ and Atrazine was $38.45 \times$, either $E$. coli. Its bacterial growth was before treatment $17.09 \times$. To show the results of growth on diazinon $30.43 \times$, Pirimicarb $27.71 \times$ and Atrazine 24.34×. While the growth was in S.bongori Before treatment $10.09 \times$ While recorded a growth rate on Diazinon 18.82×, Pirimicarb 19.98× and Atrazine $17.08 \times$. These bacterial species efficiencies on bioremediation of these three pesticides proved to be promising It can be used safely in the process of removing pesticides, yet more research on safety, mechanisms and kinetics needs to be further investigated.

\section{Introduction}

Pesticides are chemical compounds that are used to combat pests, including insects, rodents, fungi and unwanted plants (weeds). Pesticides are used in public health to fight vectors of disease, such as mosquitoes, and in agriculture, to combat pests that damage crops. By their nature, pesticides are potentially toxic to other organisms, including humans, and need to be used safely and disposed-off properly (WHO, 2019). Pesticides are applied to agricultural crops annually for pest control worldwide It is estimated that less than $1 \%$ of the total applied pesticides generally gets to the target pests and most of the pesticides remain unused and enter into the ecosystem. The ultimate sink for excessive pesticides is soil and water (Kuhad, et al., 2013). There is a vital need to remediate and clean heavily polluted soil with pesticides and pesticides 
residues. Among various soil remediation technologies available today for decontamination and detoxication of pesticide-contaminated soils, bioremediation seems to be one of the most environmentallysafe and cost- effective methods. Bioremediation refers to the use of microorganisms (Bacteria, fungi) or green plant to degrade contaminants that pose environmental and human risks. The versatility of microbes to degrade a vast array of pollutants makes bioremediation processes typically involve the actions of many different microbes acting in parallel or sequence to complete the degradation process. Bioremediation is a technology that can be applied in different conditions. Though it can be inexpensive and in situ approaches can reduce disruptive engineering practices, bioremediation is still not a common practice (microbewiki ,2018).Bacteria are widely diverse organisms, and thus make excellent players in biodegradation and bioremediation. There are few universal toxins to bacteria, so there is likely an organism able to breakdown any given substrate, when provided with the right conditions (Anaerobic vs. aerobic environment, sufficient electron donors or acceptors, etc.) (Microbewiki, 2018). Hence, the present study was carried out to Isolation and characterization of bacterial species that have ability to bioremediation of pesticides. Determine the efficiency of isolated bacterial species on bioremediation of pesticides diazinon, pirimicarb and atrazine. Evaluation of the level of pesticide removal by bacterial species and Comparison of growth rate of bacterial cells in pesticides.

\section{Materials and Methods}

\section{Sample collection}

The soil samples were collected from farm to the western side of the University of Gezira at $14.3858^{\circ} \mathrm{N}, 33.5294^{\circ} \mathrm{E}$ in Wad Medani city, Sudan.

\section{Design and statistical analysis}

The experimental layout was a randomized complete block (RCB) design in split plot system, with three replicates. Data was subjected to ANOVA using the Statistical Analysis System (CoStat's) Statistical Procedures and treatment means were compared using the revised L.S.D. test at a 0.05 level according to (Robert George and Douglas Steel, 1997).

\section{Pesticides used in this study}

Three concentrations were prepared from the standard pesticide solution $100 \mathrm{ppm}, i$. e. 10 ppm, 25 ppm and 50 ppm.

\begin{tabular}{|c|l|l|l|l|}
\hline No & Pesticide & Group & Type & $\begin{array}{l}\text { Chemical } \\
\text { formula }\end{array}$ \\
\hline 1 & diazinon & OP & Insecticide & $\mathrm{C}_{12} \mathrm{H}_{21} \mathbf{N}_{2} \mathrm{O}_{3}$ PS \\
\hline 2 & pirimicarb & carbamate & Insecticide & $\mathrm{C}_{11} \mathrm{H}_{18} \mathbf{N}_{4} \mathrm{O}_{2}$ \\
\hline 3 & atrazine & triazine & Herbicides & $\mathrm{C}_{8} \mathrm{H}_{14} \mathrm{CIN}_{5}$ \\
\hline
\end{tabular}

\section{Isolation and identification of bacterial isolates}

Serial folds dilution technique was used for the isolation of pesticide degrading bacteria in nutrient agar. Well grown bacterial colonies were picked and further purified .The purified isolates were identified according to criteria described by Barrow and Feltham (2003). This included staining reaction, organism morphology, growth conditions, colony characteristics on different media, and biochemical characteristics.

\section{Counting bacterial cells}

1. Total viable cells.

2. Total nonviable cells.

3. Percentage of viable cells:

$\%$ of viable cells $=\frac{\text { viable cells }}{\text { total of cell }} \times 100$ 
4. Average of cell / square :

$$
=\frac{\text { viable cell }}{\text { squaer }}
$$

\section{Dilution factor:}

$$
=\frac{\text { final volume }}{\text { volume of cell }}
$$

6. Concentration (viable cell / ml):

$=$ average of cell $/$ square $x$ dilution factor $x$ $10^{4}$.

\section{Bioremediation process of pesticides by isolated bacteria}

The tubes are equipped with autoclave for 40 min at $120{ }^{\circ} \mathrm{C}$ and Activation of bacteria. The vaccine was prepared by adding 1-3 colonies of bacteria in normal saline 8 . Five $\mathrm{g}$ of $\mathrm{NaCl}$ .Then Ten $\mathrm{ml}$ of Broth Culture Liquid media was placed in each tube. $1 \mathrm{ml}$ of pesticides at the required concentrations (10 ppm - $25 \mathrm{ppm}$ - $50 \mathrm{ppm}$ ) was added. $1 \mathrm{ml}$ of bacteria solution to the tubes was added. After that The incubation process was done by placing the tubes at $37{ }^{\circ} \mathrm{C}$ in a shaking water bath The results were taken after $24 \mathrm{hr}$. by taking $5 \mathrm{ml}$ of the treated solution after excluding the leachate and taking the top extracted by centrifuge. Finally $5 \mathrm{ml}$ acetonitrile (CAN) was added to stop the activity of the bacteria in the extract.

\section{Processing of samples for separation and extraction processes}

After extracting $5 \mathrm{ml}$ of the sample solution, QuEChERS extraction materials were added to the sample, consisting of $4 \mathrm{mg} \mathrm{MgSO}_{4}$ and $1 \mathrm{NaAC}$. The samples were then placed in a centrifuge for 5 minutes at $4000 \mathrm{rpm}$ and the supernatant was withdrawn from the samples. Then the samples were concentrated using 0.5 $\mathrm{mL}$ nitrogen. The calibration curve concentrations were prepared to determine the accuracy of the experiment into the GC/ MS and analyze.

Calculation of Pesticides decomposition rate

concentrate solution before treatment-concentrate solution after treatment concentrate solution before treatment

Isolation and characterization of bacterial species that have ability to bioremediation of pesticides

The bacteria were identified Staphylococcus aureus, Salmonella bongori and Escherichia coli from soil to use for the bioremediation of pesticides. The results of analysis of the biochemical properties of bacterial species isolated from different samples are shown in the Table (1).

Determine the efficiency of isolated bacterial species on bioremediation of pesticides diazinon, pirimicarb and atrazine

The results of the interaction effects between the three studied factors bacteria, pesticides and pesticide concentrations in bioremediation of pesticides was recorded for S.aureus against atrazine for $50 \mathrm{ppm}$ concentration, followed by S.aureus with Diazinon at a concentration level of 50ppm and the S.aureus with atrazine at a concentration level of $25 \mathrm{ppm}$ while, the lowest value was found in $E$. coli with Pirimicarb at concentration level of $10 \mathrm{ppm}$ followed S.bongori with Diazinon in concentration 10ppm and S.bongori with atrazine at a concentration of 10ppm, which were presented in Table (2). From the previous results, we found that, there are significant differences between the types of bacteria in bioremediation efficiency Table (3). The $S$. aureus bacteria was the most effective species (63.99\%). E.coli bacteria had an average efficiency of $58.21 \%$. Finally, 
S.bongori bacteria are considered to be effective as low as $56.63 \%$.

\section{Evaluation of the level of pesticide removal by bacterial species}

In the treatment of pesticides with each bacterium separately, it was found that Diazinon and Pirimicarb scored the highest value compared to Atrazine Table (4).

\section{Comparison of growth rate of bacterial cells in pesticides}

When comparing the growth rate of bacterial cells. The bacterial cells before treatment with S. aureus was $22.01 \times$, Results after treatment showed diazinon of $35.58 \times$. The Pirimicarb $32.41 \times$ and atrazine was $38.45 \times($ Fig. 1) Either E. coli Its bacterial growth was before treatment $17.09 \times$ To show the results of growth on diazinon $30.43 \times$, Pirimicarb $27.71 \times$ and atrazine $24.34 \times$ (Fig. 2) While the growth was in $S$. bongori. Before treatment $10.09 \times$ While recorded a growth rate on diazinon $18.82 \times$, Pirimicarb 19.98x and atrazine $17.08 \times$ (Fig. 3 ).

Reported results showed clearly that, the bacterium S.aureus have the highest capacity and efficiency in bioremediation processes, showing proportion of analytical efficiency of $63.99 \%$ at concentration levels of the three pesticides. Then followed by bacteria $E$. coli with a medium efficiency is achieved for a percentage of $58.21 \%$. This result is consistent with (Radhika and Kannahi, 2014). They reported that S.aureus and E. coli in bioremediation of Permethrin. The S.bongori bacteria have shown the lowest level of efficiency of $56.36 \%$, with a slight difference from E. coli. It is possible to say that these results are consistent with many previous studies that show the ability of microorganisms such as fungi and bacteria to consume a wide range of pesticides. In most cases the ability of microorganisms to consume one or more compounds as a source of energy and carbon (Alzawy et al., 2013). It is also observed when comparing the growth of bacterial cells to the species used in bioremediation. The superiority of S.aureus bacteria was observed as the growth rate of bacterial cells at the concentration levels of Diazinon, Pirimicarb and Atrazine where it was $38.01 \times, 35.36 \times$ and $33.43 \times$ Respectively, as well as bacteria E. coli $32.22 \times, 30.43 \times$ and $31.43^{*}$. Either bacteria $S$. bongori which is less efficient and also the least growth rate $21.58 \times, 22.89 \times$ and $20.71 \times$ respectively.

Table.1 Biochemical test of Escherichia coli, Salmonella bongori and Staphylococcus aureus

\begin{tabular}{|c|l|c|c|c|}
\hline No & Tests & S.bongori & E.coli & S.aureus \\
\hline $\mathbf{1}$ & Indole & - & + & - \\
\hline $\mathbf{2}$ & Methyl Red (MR) & + & + & + \\
\hline $\mathbf{3}$ & Urease test & - & - & + \\
\hline $\mathbf{4}$ & Catalase & + & + & + \\
\hline $\mathbf{5}$ & Motility & + & + & - \\
\hline $\mathbf{6}$ & Citrate & + & - & - \\
\hline $\mathbf{7}$ & Gram test & - & - & + \\
\hline
\end{tabular}


Table. 2 Effect of interaction between bacteria, pesticides and pesticide concentrations on the ratio of biological treatment

\begin{tabular}{|c|c|c|c|}
\hline Bacteria & Pesticides & Con / ppm & Result \\
\hline & Diazinon & 10 & $59.03 \mathrm{~d}-\mathrm{g}$ \\
\hline & & 25 & $60.76 \mathrm{c}-\mathrm{e}$ \\
\hline & & 50 & $63.63 \mathrm{a}-\mathrm{e}$ \\
\hline & Pirimicarb & 10 & $44.33 \mathrm{k}$ \\
\hline & & 25 & $52.83 \mathrm{f}-\mathrm{j}$ \\
\hline \multirow[t]{9}{*}{ E. coli } & & 50 & $60.93 \mathrm{~b}-\mathrm{e}$ \\
\hline & Atrazine & 10 & $57.30 \mathrm{e}-\mathrm{i}$ \\
\hline & & 25 & $60.63 c-f$ \\
\hline & & 50 & $64.46 \mathrm{a}-\mathrm{e}$ \\
\hline & Diazinon & 10 & $62.33 \mathrm{~b}-\mathrm{e}$ \\
\hline & & 25 & $63.40 \mathrm{a}-\mathrm{e}$ \\
\hline & & 50 & $68.66 a-b$ \\
\hline & Pirimicarb & 10 & $59.33 \mathrm{c}-\mathrm{g}$ \\
\hline & & 25 & $61.53 \mathrm{~b}-\mathrm{e}$ \\
\hline \multirow[t]{9}{*}{ S. aureus } & & 50 & $64.50 \mathrm{a}-\mathrm{e}$ \\
\hline & Atrazine & 10 & $60.33 c-f$ \\
\hline & & 25 & $65.26 \mathrm{a}-\mathrm{d}$ \\
\hline & & 50 & $70.53 a$ \\
\hline & Diazinon & 10 & $49.56 \mathrm{i}-\mathrm{k}$ \\
\hline & & 25 & $51.73 \mathrm{~g}-\mathrm{k}$ \\
\hline & & 50 & $58.33 \mathrm{~d}-\mathrm{g}$ \\
\hline & Pirimicarb & 10 & $61.33 \mathrm{~b}-\mathrm{e}$ \\
\hline & & 25 & $63.50 \mathrm{a}-\mathrm{e}$ \\
\hline \multirow[t]{4}{*}{ S. bongori } & & 50 & $66.96 \mathrm{a}-\mathrm{c}$ \\
\hline & Atrazine & 10 & $48.26 \mathrm{j}-\mathrm{k}$ \\
\hline & & 25 & $50.13 \mathrm{~h}-\mathrm{k}$ \\
\hline & & 50 & $57.43 \mathrm{e}-\mathrm{h}$ \\
\hline
\end{tabular}

Values having the same alphabetical letter (s) are not significantly different from one another, using revised L.S.D. test at 0.05 level of probability

Table.3 Comparison of the efficiency of single bacteria in bioremediation of pesticides

\begin{tabular}{|l|l|}
\hline Bacteria & Result \\
\hline E.coli & $58.21 \mathrm{~b}$ \\
\hline S. aureus & $63.99 \mathrm{a}$ \\
\hline S. bongori & $56.36 \mathrm{c}$ \\
\hline
\end{tabular}

Values having the same alphabetical letter (s) are not significantly different from one another, using revised L.S.D. test at 0.05 level of probability 
Table.4 Compared to the efficiency of the decomposition of pesticides with individual bacteria

\begin{tabular}{|l|l|}
\hline Pesticides & Result \\
\hline Diazinon & $62.73 \mathrm{a}$ \\
\hline Pirimicarb & $64.07 \mathrm{a} \mathrm{b}$ \\
\hline Atrazine & $58.67 \mathrm{~b}$ \\
\hline
\end{tabular}

Values having the same alphabetical letter (s) are not significantly different from one another, using revised L.S.D. test at 0.05 level of probability.

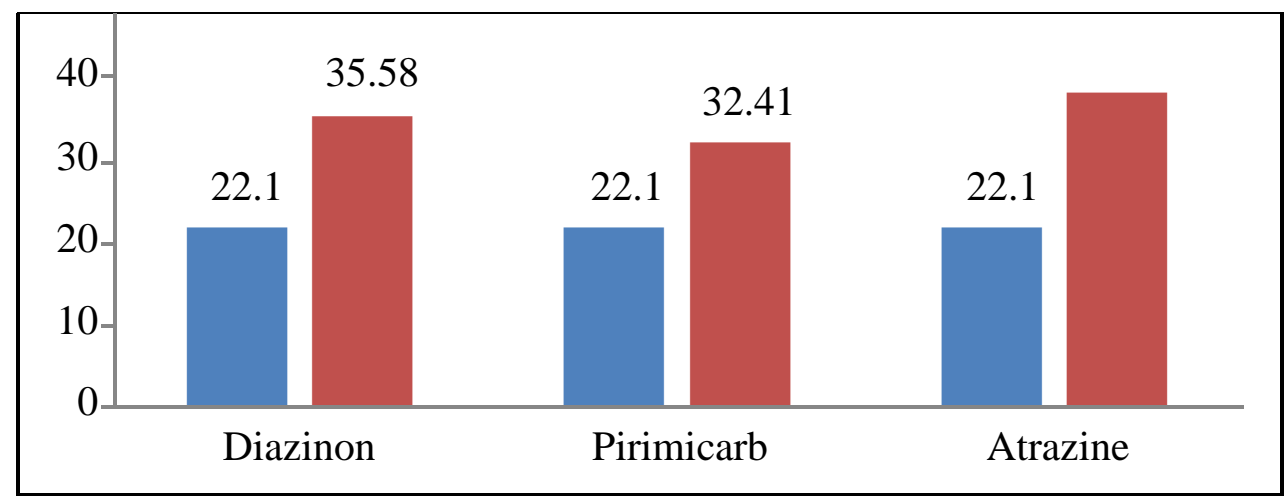

Figure.1 S.aureus growth rate

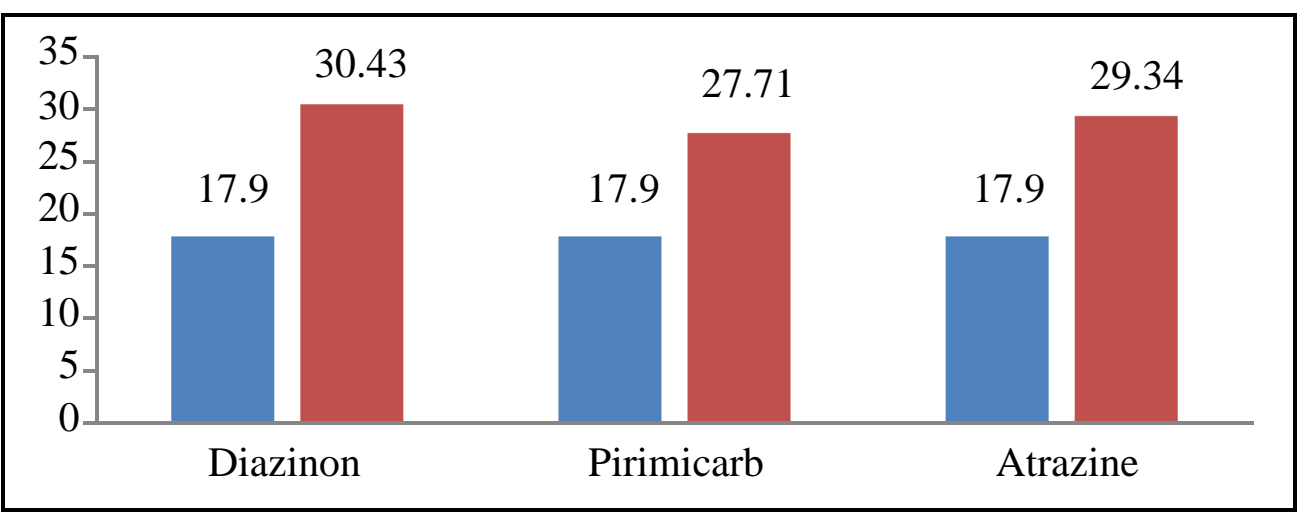

Figure.2 E. coli growth rate

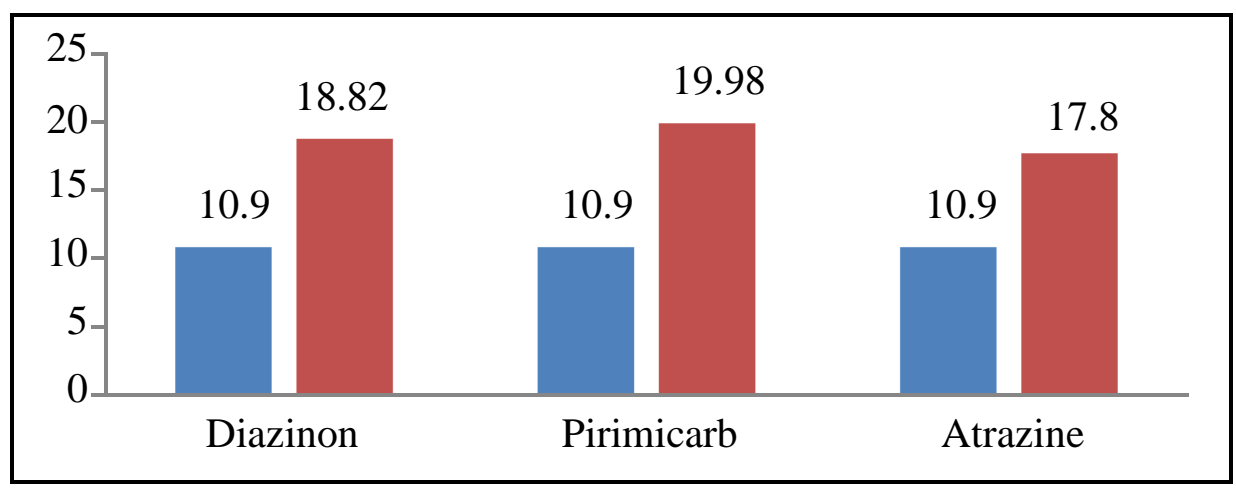

Figure.3 S.bongori growth rate 
This indicates that bacteria are unable to take advantage of the carbon and energy present in the pesticide to help them in this growth and reproduction process, thus facilitating the growth of bacterial cells. In the end, the overall result is either the elimination of the pesticide or its conversion to other compounds as a result of metabolism. The above findings indicate that there are clear general differences combination mixture of bacteria and pesticides, but at different scales, with regard to the overall trend of pesticide degradation. In the results of the analysis of pesticides with the single treatment of bacteria; it is found that, the pesticide Atrazine have the lowest rate of decomposition of $58.67 \%$, compared to pesticides Pirimicarb $64.07 \%$ and Diazinon $62.73 \%$, although there were no significant differences between them through statistical analysis, however, they gave the highest proportion of decomposition. Focusing on the results obtained from the treatment of pesticides with bacteria mixtures. It was found that the Atrazine pesticide reported the lowest decomposition rate of $65.03 \%$ compared to Diazinon $76.33 \%$ and Pirimicarb $71.65 \%$. Based on the results obtained, it can be said that the Atrazine pesticide has a relatively simple decomposition characteristic, these results are consistent with (kookana et al.,1995), who concluded on others pesticides such as Atrazine and Simazine are biodegradable at slow rates and may by leached from soil to ground water .Conversely, we found that pesticide Diazinon achieved high decomposition rate, this depict its biodegradability, this supported by the results of (Kookana et al., 1995), which elucidated some pesticides that are more readily biodegradable such as organophosphate. Previous results for Diazinon reported that bacteria Staphylococcus achieved the highest decomposition with concentration level of $50 \mathrm{ppm}$ resulted in decomposition of up to
$68.66 \%$, this result is different from the results obtained by (Tamer Mohamed et al., 2013), which shows non-significant effect on bacterial Diazinon degradation, and that bacteria pseudomonas and bacillus showed the ability to degrade Diazinon insecticides more than the others. For the pesticide Pirimicarb we found that it has achieved a high rate of biodegradation. It is very close to the chemical properties and the toxic act of the pesticide Diazinon. In general, if one considers the difference in microbiology in its physiological properties and its ability to metabolize many substances, it uses different pesticides as its food, which it represents in two ways. First, the chemical supports the growth of microorganisms Where they are used as a source of carbon and energy as happened to Pirimicarb and Diazinon, and sometimes as a source of nitrogen like atrazine, this is consistent with the report (Mandelbaum et al., 1995). In this case; the density of the number of bacteria and disappearance or lack of chemical compound is predominant.

In conclusion, the bacterial species isolated from soil especially Staphylococcus aureus showed the ability to degrade pesticides. Bacteria E.coli and salmonalla bongori showed less efficiency in decomposition but could benefit from them. Diazinon and Pirimicarb are highly susceptible to degradation compared to pesticide Atrazine.

\section{References}

Barrow, G. I. and Feltham, R. K. A. (2003). Cowan and Steel's Manual for the identification of the Medical Bacteria, 3rd "edition. Cambridge University Press, Cambridge, U. K.

Radhika, M and M. Kannahi (2014). Bioremediation of pesticide (Cypermethrin) using bacterial species in contaminated soil. 
Int.J.Curr.Microbiol.App.Sci 3(7): 427435.

Microbe wiki (2018). Bioremediation.

https://microbewiki.kenyon.edu/index.php/Bi oremediation

Ramesh C. Kuhad, Atul K. Johni, Ajay Singh, Owen P. Ward (2013). Applied Bioremediation and Phytoremediation. Springer Science \& Business Media.

Raphi T. Mandelbaum, Deborah L. Allan, And Lawrence P. Wackett (1995). Isolation and Characterization of a Pseudomonas sp. That Mineralizes the s-Triazine Herbicide Atrazine. Applied And Environmental Microbiology. p. 1451-1457.

Robert George and Douglas Steel (1997).
Principles and procedures of statistics: a biometrical approach. New York. McGraw-Hill.

Kookana, RS, HJ Di and LAG Aylmore (1995). A field-study of leaching and degradation of nine pesticides in a sandy soil. Australian Journal of Soil Research 33(6) 1019 - 1030 Published

Tamer Mohamed Ahmed Mohamed Thabit and Medhat Ahmed Hassan El-

Naggar (2013). Diazinon decomposition by soil bacteria and identification of degradation products by GC-MS. Soil Environ. 32(2): 96-102.

World Health Organization (WHO, 2019), https://www.who.int/topics/pesticides/e

n

\section{How to cite this article:}

Mosaab Abdalmahmoud Hassan, Aarif El-Mubarak and Yousif Osman Assad. 2020. Effectiveness evaluation of Bacterial Species Isolated from soil in Bioremediation of Diazinon, Pirimicarb and Atrazine Pesticides. Int.J.Curr.Microbiol.App.Sci. 9(03): 914-921. doi: https://doi.org/10.20546/ijcmas.2020.903.107 